\title{
Altererythrobacter ishigakiensis sp. nov., an astaxanthin-producing bacterium isolated from a marine sediment
}

Correspondence

Tadashi Matsunaga

tmatsuna@cc.tuat.ac.jp

\author{
Mitsufumi Matsumoto, ${ }^{1,2}$ Daisuke Iwama, ${ }^{1}$ Atsushi Arakaki, ${ }^{1}$ \\ Akira Tanaka, ${ }^{1}$ Tsuyoshi Tanaka, ${ }^{1}$ Hideaki Miyashita ${ }^{3}$ \\ and Tadashi Matsunaga ${ }^{1}$ \\ ${ }^{1}$ Department of Biotechnology, Tokyo University of Agriculture and Technology, 2-24-16, \\ Naka-cho, Koganei, Tokyo 184-8588, Japan \\ ${ }^{2}$ Biotechnology Laboratory, Electric Power Development Co., 1, Yanagisaki-machi, \\ Wakamatsu-ku, Kitakyusyu 808-0111, Japan \\ ${ }^{3}$ Department of Technology and Ecology, Hall of Global Environmental Studies, \\ Kyoto University, Yoshida-Honmachi, Sakyo-ku, Kyoto 606-8501, Japan
}

\begin{abstract}
A Gram-negative, non-motile, non-spore-forming, halophilic rod, designated JPCCMB0017 ${ }^{\top}$, was isolated from a marine sediment of the coastal area of Okinawa, Japan. The isolate formed orange-red colonies on marine agar. Bacteriochlorophyll $\alpha$ was absent and sphingoglycolipid 1 and other carotenoids, including astaxanthin, adonixanthin and zeaxanthin, were present. Ubiquinone-10 (Q-10) was the main respiratory quinone and $\mathrm{C}_{18: 1} \omega 7 \mathrm{c}$ was the major cellular fatty acid. The $\mathrm{G}+\mathrm{C}$ content of DNA was $59.1 \mathrm{~mol} \%$. Phylogenetic analysis based on $16 \mathrm{~S}$ rRNA gene sequencing revealed that the isolate was a member of the genus Altererythrobacter in the family Erythrobacteraceae. Strain JPCCMB0017 $7^{\top}$ exhibited 96.8\% 16S rRNA gene sequence similarity with Altererythrobacter marinus $\mathrm{H} 32^{\top}$. Unlike other members of the genus Altererythrobacter, strain JPCCMB0017 $7^{\top}$ reduced nitrate. On the basis of genotypic and phenotypic data, a novel species is proposed to accommodate this isolate, with the name Altererythrobacter ishigakiensis sp. nov. The type strain is JPCCMB0017 ${ }^{\top}$ $\left(=\right.$ NITE$^{-A P} 48^{\top}=$ ATCC BAA-2084 ${ }^{\top}=$ NBRC $\left.107699^{\top}\right)$.
\end{abstract}

Astaxanthin $\left(3,3^{\prime}\right.$-dihydroxy- $\beta, \beta$-caroten- $4,4^{\prime}$-dione $)$ is a carotenoid pigment with several essential biological functions and wide applications in the nutraceutical, cosmetic, food and animal feed industries (Lorenz \& Cysewski, 2000). Astaxanthin is produced by micro-organisms such as green microalgae (Bar et al., 1995; Renstrom et al., 1981), red yeasts (Andrewes et al., 1976) and members of diverse bacterial genera such as Paracoccus (Tsubokura et al., 1999), Sphingomonas (Asker et al., 2007), Brevundimonas (Iizuka \& Nishimura, 1969) and Bacillus (Pane et al., 1996).

The genus Altererythrobacter was proposed by Kwon et al. (2007). At present, this genus includes eight species with validly published names: Altererythrobacter luteolus (Yoon et al., 2005), A. epoxidivorans (Kwon et al., 2007), A. indicus (Kumar et al., 2008), A. marinus (Lai et al., 2009), A. marensis

Abbreviations: BChl, bacteriochlorophyll; SGL-1, sphingoglycolipid.

The GenBank/EMBL/DDBJ accession number for the 16S rRNA gene sequence of strain NITE-AP48 ${ }^{\top}$ is AB363004.

A supplementary figure and two supplementary tables are available with the online version of this paper.
(Seo \& Lee, 2010), A. dongtanensis (Fan et al., 2011), A. namhicola and A. aestuarii (Park et al., 2011). The genus is phylogenetically related to four other genera, namely Erythrobacter, Porphyrobacter, Erythromicrobium and Croceicoccus, which together constitute the family Erythrobacteraceae. Members of the genus Altererythrobacter exhibit some common characteristics, such as non-motility, lack of bacteriochlorophyll (BChl) $\alpha$ and the requirement for sodium for cell growth (Kumar et al., 2008). Cells form yellow-pigmented colonies, but the origin of the colour remains to be clarified.

During the screening of astaxanthin-producing bacteria from marine sediments, we isolated a halophilic bacterium, designated JPCCMB0017 ${ }^{\mathrm{T}}$, which produced orange-red pigments. Marine sediments were collected from a site on the coast of Ishigaki island, Okinawa, Japan. Samples were suspended in sterile seawater and, after sedimentation, the supernatant was diluted 10- to 1000 -fold and spread on 10-fold diluted marine agar 2216 (MA; Difco) or YPG medium $[0.1 \%$ bactopeptone, $0.05 \%$ yeast extract and $0.1 \%$ glucose; artificial seawater (Marine Art SF-1, Tomita Pharmaceutical Co., Ltd.)]. After incubation for 2 weeks at 
$25{ }^{\circ} \mathrm{C}$, orange-red colonies were obtained, one of which was strain JPCCMB0017 $7^{\mathrm{T}}$ and was subsequently cultured in marine broth 2216 (MB; Difco).

Gram-staining, mobility and cell morphology were determined by phase-contrast microscopy and transmission electron microscopy (JEM 2000EX; JEOL). To evaluate the effect of $0-3.0 \%(\mathrm{w} / \mathrm{v}) \mathrm{NaCl}$ on growth, the bacterium was cultured in liquid BY medium (1.5\% bactopeptone, $0.5 \%$ yeast extract, $0.006 \% \mathrm{KH}_{2} \mathrm{PO}_{4}, 0.005 \% \mathrm{FeSO}_{4}, 0.88 \%$ $\mathrm{MgCl}_{2}, 0.18 \% \mathrm{CaCl}_{2}, 2.0 \% \mathrm{NaCl}$; distilled water; $\mathrm{pH} 7.5$ ) and $\mathrm{NaCl}$ was replaced with $\mathrm{KCl}$ in addition to the supplementation with $\mathrm{NaCl}$. To evaluate the optimum $\mathrm{pH}$ for growth, the bacterium was cultured in liquid BY medium at $\mathrm{pH}$ 5.5-8.5. Colonies on MA were used for the analysis of cytochrome oxidase activity with a commercial paper disc (Oxidase test; bioMérieux) and catalase activity with $0.3 \%$ hydrogen peroxide. Other biochemical tests, including that to determine nitrate reduction, were conducted using the API 20 NE system (bioMérieux), according to the manufacturer's instructions.

Genomic DNA was extracted by standard procedures (Sambrook et al., 1989). The 16S rRNA gene was amplified by PCR and sequenced using universal primers: the forward primers corresponded to nucleotide positions 827 (5'-AGAGTTTGATCCTGGCTCAG-3') and 340-356 (5'-CCTACGGGAGGCAGCAG-3') of the Escherichia coli
$16 \mathrm{~S}$ rRNA gene and the reverse primers corresponded to positions 906-925 (5'-CCGTCAATTCCTTTAAGTTT-3') and 1492-1510 (5'-GGCTACCTTGTTACGACTT-3'). A partial sequence (1315 bp) was subjected to BLAST against sequences in the DDBJ database (Altschul et al., 1990). The multiple sequence alignment was analysed using CLUSTAL $\mathrm{W}$ (Thompson et al., 1994) and a phylogenetic tree was constructed using the neighbour-joining method (Saitou \& Nei, 1987) with MEGA version 4.0 (Kumar et al., 2004).

For chemotaxonomic analyses, biomass was obtained from cultures grown in $\mathrm{MB}$ for 3 days at $30^{\circ} \mathrm{C}$. The $\mathrm{G}+\mathrm{C}$ content of DNA was determined by the method of Katayama-Fujimura et al. (1984). Quinones were analysed by the methods described elsewhere (Nishijima et al., 1997; Yokota et al., 1992). Pigments were extracted from 50$100 \mathrm{mg}$ dry cells using $5 \mathrm{ml}$ dichloromethane/methanol $(3: 1, v / v)$. The extracts were dried using $\mathrm{N}_{2}$ gas, resuspended in acetone and acetonitrile for TLC and HPLC, respectively, filtered through a $0.5 \mu \mathrm{m}$ polytetrafluoroethylene membrane filter and subsequently loaded onto a HPLC column (Symmetry C18, $5 \mu \mathrm{m}, 150 \mathrm{~mm}$; Waters). The mobile phase was a mixture of acetonitrile/ methanol/2-propanol $(45: 3: 2, \mathrm{v} / \mathrm{v})$. Pigments were monitored by measuring absorbance at approximately $480 \mathrm{~nm}$. Carotenoid contents were quantified by comparing the peak area with those of the standard synthetic carotenoid

Table 1. Phenotypic characteristics of strain JPCCMB0017 ${ }^{\top}$ and the type strains of species of the genera Altererythrobacter and Croceicoccus

Strains: 1, JPCCMB0017 ${ }^{\mathrm{T}}$ (data from this study); 2, A. marinus $\mathrm{H} 32^{\mathrm{T}}$ (Lai et al., 2009); 3, A. marensis MSW-14 ${ }^{\mathrm{T}}$ (Seo \& Lee, 2010); 4, A. luteolus SW-109 ${ }^{\mathrm{T}}$ (Yoon et al., 2005); 5. A. indicus MSSRF26 ${ }^{\mathrm{T}}$ (Kumar et al., 2008); 6, A. dongtanensis JM27 ${ }^{\mathrm{T}}$ (Fan et al., 2011); 7, A. namhicola KYW48 ${ }^{\mathrm{T}}$ (Park et al., 2011); 8, A. aestuarii KYW147 ${ }^{\mathrm{T}}$ (Park et al., 2011); 9, A. epoxidivorans JCS $350^{\mathrm{T}}$ (Kwon et al., 2007); 10, Croceicoccus marinus E4A9 ${ }^{\mathrm{T}}$ (Xu et al., 2009). Data in parentheses were taken from this study. O, Orange; OR, orange-red; Y, yellow; +, positive; w, weakly positive; -, negative; ND, no data available.

\begin{tabular}{|c|c|c|c|c|c|c|c|c|c|c|}
\hline Characteristic & 1 & 2 & 3 & 4 & 5 & 6 & 7 & 8 & 9 & 10 \\
\hline Oxidase & + & - & + & + & - & - & + & + & + & - \\
\hline Motility & - & - & + & - & - & - & - & - & - & + \\
\hline $\begin{array}{l}\text { DNA G }+C \text { content } \\
(\mathrm{mol} \%)\end{array}$ & 59.1 & 66.5 & 63.1 & 60.3 & 66.8 & 66.4 & 63.8 & 67.2 & 54.5 & 71.5 \\
\hline Aesculin & + & $+(+)$ & $+(+)$ & $+(\mathrm{w})$ & $+(+)$ & - & + & + & $-(\mathrm{w})$ & + \\
\hline Gelatin & - & $-(-)$ & $-(-)$ & $-(-)$ & $\mathrm{ND}(-) \dagger$ & - & - & - & $-(-)$ & + \\
\hline \multicolumn{11}{|l|}{ Utilization of: } \\
\hline D-Glucose & - & $-(-)$ & $-(-)$ & $+(+)$ & $+(+)$ & + & - & - & $-(-)$ & + \\
\hline D-Mannose & - & $-(-)$ & $-(-)$ & $-(-)$ & $\mathrm{ND}(-)$ & - & - & - & $\mathrm{ND}(-)$ & + \\
\hline
\end{tabular}

*Also reported as negative by Fan et al. (2011).

$\dagger$ Also reported as negative by Lai et al. (2009). 
solutions. Fatty acids were analysed by the methods described in Yabuuchi et al. (1990, 1999). Dried cells (3 mg) were added to $2 \mathrm{ml} \mathrm{HCl} /$ methanol $(1: 19$, w/v). The mixture was shaken vigorously and incubated at $90{ }^{\circ} \mathrm{C}$ for $45 \mathrm{~min}$. Fatty acid methyl esters were extracted rapidly from cooled mixtures by washing with $1.5 \mathrm{ml} \mathrm{n}$-hexane. The obtained samples were analysed by GC/MS (QP2010; Shimadzu) using a capillary column (CBP5-M25-025; Shimadzu) under the following conditions: ionizing voltage, $70 \mathrm{eV}$; ionizing current, $60 \mu \mathrm{A}$; interface temperature, $250{ }^{\circ} \mathrm{C}$; injection-port temperature, $240{ }^{\circ} \mathrm{C}$; and helium gas pressure, $100 \mathrm{kPa}$. The initial column temperature was $80{ }^{\circ} \mathrm{C}$ for 2 min and was ramped to $240{ }^{\circ} \mathrm{C}$ at a rate of $4{ }^{\circ} \mathrm{C} \mathrm{min}{ }^{-1}$. Fatty acid methyl esters were identified by comparing the retention time of peaks and the mass spectra of samples with those of a standard fatty acid mixture (Funakoshi).
The presence of sphingoglycolipids (SGLs) in cells was analysed according to Kawahara et al. (1991). Dried cells were homogenized with chloroform/methanol $(4: 1, \mathrm{v} / \mathrm{v})$ to remove phospholipids. For the extraction of SGLs, the residual cells were homogenized with chloroform/methanol $(1: 1, \mathrm{v} / \mathrm{v})$ at room temperature and then with chloroform/methanol $(1: 3, \mathrm{v} / \mathrm{v})$ at $80{ }^{\circ} \mathrm{C}$ for $60 \mathrm{~min}$ with stirring. The extracts were combined and applied to a silica-gel 60 column (70-230 mesh; Merck, Germany). SGLs were eluted using chloroform/methanol $(2: 1$ and $1: 3)$ and the elution profile was obtained by TLC using silica-gel 60 (aluminium plates; Merck). The SGL-containing fractions were pooled and hydrolysed with $0.1 \mathrm{M}$ $\mathrm{NaOH}$ at $100{ }^{\circ} \mathrm{C}$ for $30 \mathrm{~min}$. The hydrolysates were dialysed, lyophilized and applied to a second silica-gel 60 column to obtain purified SGLs. The chemical structure of

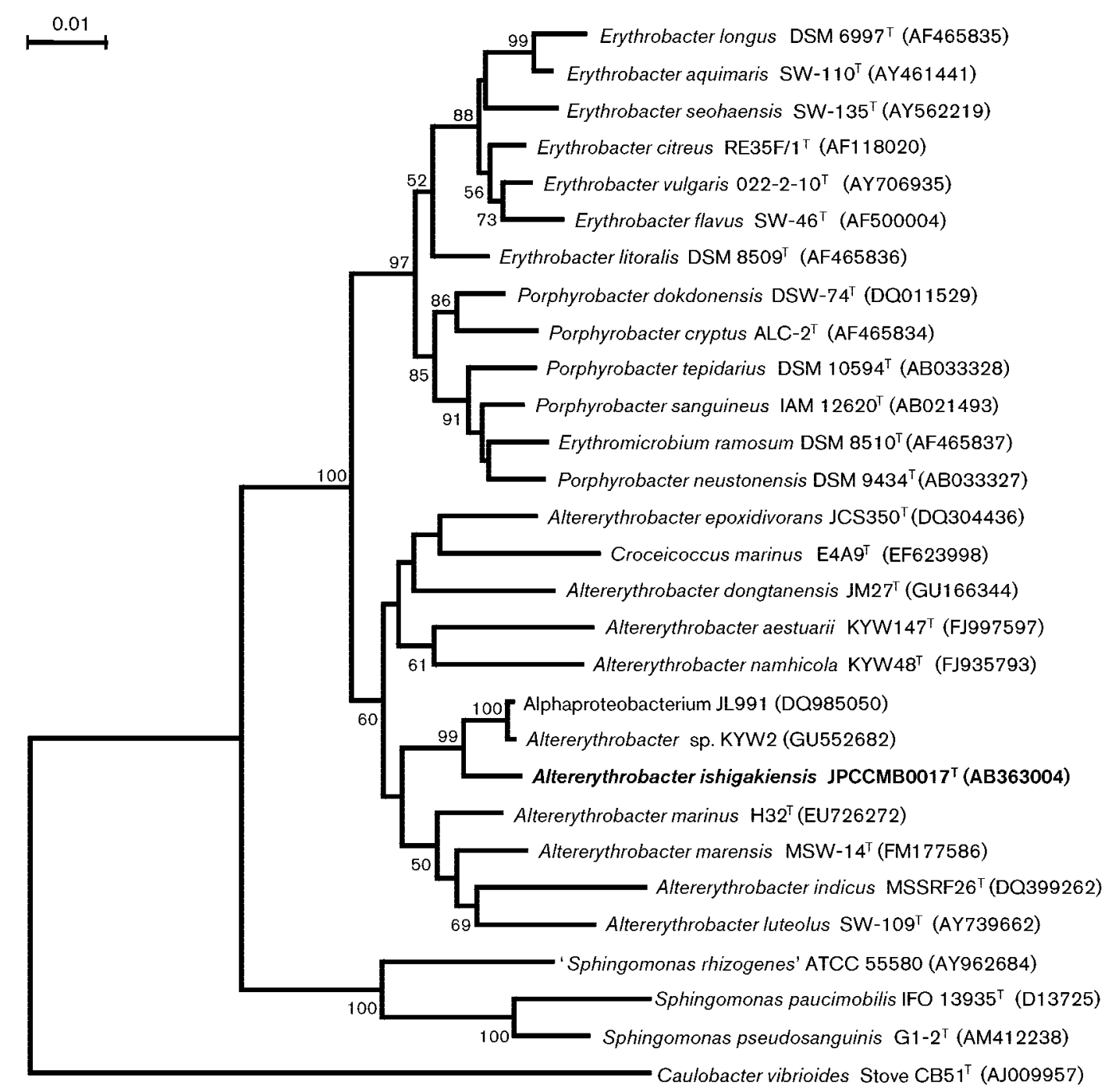

Fig. 1. Neighbour-joining phylogenetic tree based on $16 \mathrm{~S}$ rRNA gene sequences (1315 bp) showing the relationship of strain JPCCMB0017 ${ }^{\top}$ with representatives of closely related taxa in the family Erythrobacteraceae. Bootstrap values (1000 replications; $>50 \%$ ) are shown at branch nodes. Bar, 0.01 substitutions per nucleotide position. 
SGLs was determined by electrospray-ionization tandem mass spectroscopy (ESI-MS/MS; Micro LC System UltraPlusII, Micro-Tech Scientific; LCQ-DECA XP mass spectrometer, Thermo Finnigan).

Colonies of strain JPCCMB0017 ${ }^{\mathrm{T}}$ on MA were orange-red, round, convex and smooth. Cells were non-motile rods, approximately $0.3-0.5 \mu \mathrm{m}$ wide and $1.5-2.0 \mu \mathrm{m}$ long. Ultrathin sections of cells revealed the typical arrangement of a Gram-negative cell envelope (see Supplementary Fig. S1, available in IJSEM Online). Table 1 compares the phenotypic characteristics of strain JPCCMB $0017^{\mathrm{T}}$ with the type strains of the eight recognized species of the genus Altererythrobacter and Croceicoccus marinus. Strain JPCCMB0017 ${ }^{\mathrm{T}}$ tested positive for oxidase and for the hydrolysis of aesculin, but gave a negative result for the hydrolysis of gelatin, and these characteristics were similar to those of the genus Altererythrobacter. On the other hand, strain JPCCMB0017 ${ }^{\mathrm{T}}$ could be readily differentiated from members of the genus Altererythrobacter on the basis of several phenotypic properties, such as nitrate reduction, $\beta$-galactosidase activity and substrate utilization. Strain JPCCMB0017 ${ }^{\mathrm{T}}$ could be differentiated from C. marinus $\mathrm{E} 4 \mathrm{~A} 9^{\mathrm{T}}$ on the basis of several phenotypic characteristics. Non-motility, lack of BChl $\alpha$ and the specific sodium-ion requirement for growth indicated that strain JPCCMB0017 ${ }^{\mathrm{T}}$ could not be affiliated with the genera Erythromicrobium (Yurkov et al., 1994) or Porphyrobacter (Hiraishi \& Imhoff, 2005) or with Erythrobacter longus (Shiba \& Simidu, 1982) or Erythrobacter litoralis (Yurkov et al., 1994). The temperature range for growth of strain JPCCMB0017 $7^{\mathrm{T}}$ was $25-40{ }^{\circ} \mathrm{C}$ and the optimum conditions for growth were $35{ }^{\circ} \mathrm{C}, 1.5-2.0 \%$ (w/v) $\mathrm{NaCl}$ and $\mathrm{pH}$ 7.5. Cells required $\mathrm{NaCl}$ for growth, which indicated that the isolate was halophilic. The isolate was strictly aerobic and chemo-organotrophic and positive for catalase, but was negative in tests for arginine dihydrolase and urease. Q-10 was determined to be the main respiratory quinone. SGL-1 was present and BChl $\alpha$ was absent. The DNA base

Table 2. Cellular fatty acid compositions of strain JPCCMB0017 ${ }^{\top}$ and type strains of species of the genus Altererythrobacter

Strains: 1, JPCCMB0017 ${ }^{\mathrm{T}}$ (this study); 2, A. marinus $\mathrm{H}_{32}{ }^{\mathrm{T}}$ (Lai et al., 2009); 3, A. marensis MSW-14 ${ }^{\mathrm{T}}$ (Seo \& Lee, 2010); 4, A. luteolus SW-109 ${ }^{\mathrm{T}}$ (Yoon et al., 2005); 5. A. indicus MSSRF26 ${ }^{\mathrm{T}}$ (Kumar et al., 2008); 6, A. dongtanensis JM27 ${ }^{\mathrm{T}}$ (Fan et al., 2011); 7, A. namhicola KYW48 ${ }^{\mathrm{T}}$ (Park et al., 2011); 8, A. aestuarii KYW $147^{\mathrm{T}}$ (Park et al., 2011); 9, A. epoxidivorans JCS $350^{\mathrm{T}}$ (Kwon et al., 2007). Data in parentheses were taken from this study. Fatty acids representing $<1.0 \%$ of the total in all strains are not shown.

\begin{tabular}{|c|c|c|c|c|c|c|c|c|c|}
\hline Fatty acid (\%) & 1 & 2 & 3 & 4 & 5 & 6 & 7 & 8 & 9 \\
\hline $\mathrm{C}_{12: 0}$ & - & $-(2.2)$ & $-(-)$ & $-(-)$ & $-(-)$ & - & - & - & $-(-)$ \\
\hline $\mathrm{C}_{15: 0}$ & 2.0 & $-(4.1)$ & $1.6(1.1)$ & $-(-)$ & $-(-)$ & - & 3.2 & - & $-(1.5)$ \\
\hline$C_{16: 0}$ & 8.1 & $6.7(15.0)$ & $13.0(17.6)$ & $9.0(14.5)$ & $6.8(17.9)$ & 7.1 & 5.8 & 14.6 & $3.1(13.7)$ \\
\hline$C_{17: 0}$ & 1.1 & $-(1.4)$ & $-(-)$ & $-(-)$ & $-(-)$ & - & - & - & $-(-)$ \\
\hline \multicolumn{10}{|l|}{ Cyclic } \\
\hline $\mathrm{C}_{17: 0}$ cyclo & - & - & $-(-)$ & $-(-)$ & $-(-)$ & - & - & - & $6.9(4.3)$ \\
\hline $\mathrm{C}_{19: 0} \omega 8 c$ cyclo & - & $0.3(-)$ & $-(-)$ & $-(-)$ & $-(-)$ & - & - & - & $-(-)$ \\
\hline \multicolumn{10}{|l|}{ Unsaturated } \\
\hline $\mathrm{C}_{16: 1} \omega 5 c$ & 5.0 & $2.3(3.8)$ & $1.9(7.0)$ & $3.3(21.2)$ & $-(3.1)$ & 2.8 & - & - & $2.2(20.3)$ \\
\hline $\mathrm{C}_{17: 1} \omega 6 c$ & 1.6 & $4.3(1.1)$ & $6.8(-)$ & $5.1(-)$ & $5.2(-)$ & 19.8 & 19.9 & 2.9 & $-(-)$ \\
\hline 11-Methyl $\mathrm{C}_{18: 1} \omega 7 c$ & - & $25.4(14.2)$ & $-(8.8)$ & $7.1(6.8)$ & $-(-)$ & 2.2 & - & 11.0 & $-(-)$ \\
\hline \multicolumn{10}{|l|}{ Hydroxy } \\
\hline $\mathrm{C}_{12: 0} 2-\mathrm{OH}$ & 1.2 & $-(-)$ & $-(-)$ & $-(-)$ & $-(-)$ & - & - & - & $-(-)$ \\
\hline $\mathrm{C}_{14: 0} 2-\mathrm{OH}$ & 13.3 & $3.0(8.6)$ & $1.3(11.9)$ & $3.4(5.3)$ & $7.2(12.5)$ & 5.6 & 7.5 & - & $-(3.5)$ \\
\hline $\mathrm{C}_{15: 0} 2-\mathrm{OH}$ & 6.9 & $0.3(-)$ & $-(-)$ & $-(-)$ & $-(-)$ & 7.4 & 3.5 & - & $-(-)$ \\
\hline $\mathrm{C}_{16: 0} 2-\mathrm{OH}$ & 6.3 & $1.6(5.0)$ & $1.4(7.7)$ & $3.6(4.8)$ & $-(1.9)$ & 12.5 & - & 9.0 & $-(-)$ \\
\hline $\mathrm{C}_{16: 1} 2-\mathrm{OH}$ & - & $0.1(-)$ & $-(-)$ & $-(-)$ & $-(-)$ & - & - & - & $-(-)$ \\
\hline $\mathrm{C}_{18: 1} 2-\mathrm{OH}$ & - & $0.2(-)$ & $-(-)$ & $-(-)$ & $-(-)$ & 1.6 & - & - & $-(-)$ \\
\hline iso- $\mathrm{C}_{16: 0} 3-\mathrm{OH}$ & - & $0.8(-)$ & $-(-)$ & $1.0(-)$ & $-(-)$ & 0.9 & - & - & $-(-)$ \\
\hline Summed feature ${ }^{\star}$ & - & $4.5(-)$ & $8.8(2.6)$ & $13.9(1.9)$ & $1.0(-)$ & 6.1 & 22.7 & 18.4 & $32.9(3.2)$ \\
\hline
\end{tabular}

*Summed features represent two or three fatty acids that cannot be separated by the Microbial Identification System. The summed feature consisted of one or more of $\mathrm{C}_{14: 0} 3-\mathrm{OH}, \mathrm{C}_{16: 1} \omega 7 c$ and iso- $\mathrm{C}_{15: 0} 2-\mathrm{OH}$. 
composition was $59.1 \mathrm{~mol} \%$. More details of the physiological characteristics of strain JPCCMB0017 $7^{\mathrm{T}}$ are given in the species description and in Supplementary Table S1.

Preliminary 16S rRNA gene sequence comparison with BLAST indicated that strain JPCCMB0017 ${ }^{\mathrm{T}}$ was related to the family Erythrobacteraceae and a phylogenetic dendrogram was constructed with members of the genera in this family. Strain JPCCMB0017 ${ }^{\mathrm{T}}$ was clearly placed within a cluster comprising the genera Altererythrobacter and Croceicoccus (Fig. 1). Strain JPCCMB0017 ${ }^{\mathrm{T}}$ was most closely related to the uncharacterized alphaproteobacterium strain JL991 (98.7\% $16 \mathrm{~S}$ rRNA gene sequence similarity) and Altererythrobacter sp. KYW2 (98.6\%). The most closely related type strains of recognized species were $A$. marinus $\mathrm{H} 32^{\mathrm{T}}$ ( $96.8 \% 16 \mathrm{~S}$ rRNA gene sequence similarity), A. marensis MSW- $14^{\mathrm{T}}$ (96.5\%), A. luteolus SW-109 ${ }^{\mathrm{T}}(96.0 \%)$ and A. indicus MSSRF26 $6^{\mathrm{T}}(95.8 \%)$.

The major fatty acid in strain JPCCMB0017 $7^{\mathrm{T}}$ was octadecenoic acid $\left(\mathrm{C}_{18: 1} \omega 7 c ; 45.5 \%\right)$. In addition, minor amounts of 2-hydroxy-dodecanoic acid $\left(\mathrm{C}_{12: 0}\right.$ 2-OH), 2-hydroxymyristic acid $\left(\mathrm{C}_{14: 0}\right.$ 2-OH), 2-hydroxy-pentadecanoic acid $\left(\mathrm{C}_{15: 0} 2-\mathrm{OH}\right)$ and 2-hydroxy-hexadecanoic acid $\left(\mathrm{C}_{16: 0}\right.$ $2-\mathrm{OH}$ ) were found (Table 2). The fatty acid profile of the isolate was markedly similar to that of A. indicus (Kumar et al., 2008), although there were differences in the proportions of some fatty acids.

Strain JPCCMB0017 ${ }^{\mathrm{T}}$ produced the carotenoids astaxanthin, adonixanthin, zeaxanthin, canthaxanthin and echinenone (see Supplementary Table S2). The abovementioned pigments were identified in both $\mathrm{MB}$ and $\mathrm{BY}$ medium. In contrast, only zeaxanthin was detected in other members of the genus Altererythrobacter.

The phylogenetic and chemotaxonomic analysis revealed that strain JPCCMB0017 $7^{\mathrm{T}}$ is a member of the genus Altererythrobacter. However, the fatty acid composition and physiological characteristics discriminated the new isolate from members of the other species of the genus Altererythrobacter. Thus, we propose that strain JPCCMB0017 ${ }^{\mathrm{T}}$ represents a novel species, with the name Altererythrobacter ishigakiensis sp. nov.

\section{Description of Altererythrobacter ishigakiensis sp. nov.}

Altererythrobacter ishigakiensis (i.shi.ga.ki.en'sis. N.L. masc. adj. ishigakiensis of or belonging to Ishigaki island, Okinawa, Japan, where the type strain was isolated).

Cells are non-motile rods, Gram-negative and strictly aerobic $(0.3-0.5 \mu \mathrm{m}$ wide and 1.5-2.0 $\mu \mathrm{m}$ long). Colonies are orange-red, round, convex and smooth. The carotenoids astaxanthin, adonixanthin, echinenone, canthaxanthin and echinenone are present; astaxanthin, adonixanthin and zeaxanthin are the chief pigments. Optimum growth is observed at $35{ }^{\circ} \mathrm{C}, \mathrm{pH} 7.5$ and $1.5-2.0 \%(\mathrm{w} / \mathrm{v}) \mathrm{NaCl}$. Growth does not occur in the absence of $\mathrm{NaCl}$. Ubiquinone-10 is the main quinone. Bchl $a$ is not produced. Reduces nitrate, produces catalase, oxidase and $\beta$-galactosidase and hydrolyses aesculin, but does not produce arginine dihydrolase, urease or indole or hydrolyse gelatin. Glucose acidification is not observed. Does not utilize D-glucose, L-arabinose, D-mannose, D-mannitol, $N$-acetyl-D-glucosamine, maltose, potassium gluconate, $\mathrm{n}$-capric acid, adipic acid, malate, sodium citrate or phenylacetate. The major fatty acids are $\mathrm{C}_{18: 1} \omega 7 c$ and $\mathrm{C}_{14: 0} 2-\mathrm{OH}$; the minor fatty acids are $\mathrm{C}_{14: 0}, \mathrm{C}_{15: 0}, \mathrm{C}_{16: 0}$, $\mathrm{C}_{17: 0}, \mathrm{C}_{18: 0}, \mathrm{C}_{16: 1} \omega 5 c, \mathrm{C}_{17: 1} \omega 6 c, \mathrm{C}_{17: 1} \omega 8 c, \mathrm{C}_{12: 0} 2-\mathrm{OH}$, $\mathrm{C}_{15: 0} 2-\mathrm{OH}$ and $\mathrm{C}_{16: 0} 2-\mathrm{OH}$. SGL-1 is also produced.

The type strain, JPCCMB0017 ${ }^{\mathrm{T}}\left(=\mathrm{NITE}-\mathrm{AP} 48^{\mathrm{T}}=\mathrm{ATCC}\right.$ BAA $-2084^{\mathrm{T}}=$ NBRC $107699^{\mathrm{T}}$ ), was isolated from a marine sediment obtained from the coastal area of Okinawa, Japan. The DNA G+C content of the type strain is $59.1 \mathrm{~mol} \%$.

\section{Acknowledgements}

We would like to thank Mr Keito Kodera for his technical assistance.

\section{References}

Altschul, S. F., Gish, W., Miller, W., Myers, E. W. \& Lipman, D. J. (1990). Basic local alignment search tool. J Mol Biol 215, 403-410.

Andrewes, A. G., Phaff, H. J. \& Starr, M. P. (1976). Carotenoids of Phaffia rhodozyma, a red-pigmented fermenting yeast. Phytochemistry 15, 1003-1007.

Asker, D., Beppu, T. \& Ueda, K. (2007). Sphingomonas astaxanthinifaciens sp. nov., a novel astaxanthin-producing bacterium of the family Sphingomonadaceae isolated from Misasa, Tottori, Japan. FEMS Microbiol Lett 273, 140-148.

Bar, E., Rise, M., Vishkautsan, M. \& Arad, S. (1995). Pigment and structural changes in Chlorella zofingiensis upon light and nitrogen stress. J Plant Physiol 146, 527-534.

Fan, Z.-Y., Xiao, Y.-P., Hui, W., Tian, G.-R., Lee, J.-S., Lee, K. C. \& Quan, Z.-X. (2011). Altererythrobacter dongtanensis sp. nov., isolated from a tidal flat. Int J Syst Evol Microbiol 61, 2035-2039.

Hiraishi, A. \& Imhoff, J. F. (2005). Genus VII. Porphyrobacter Fuerst, Hawkins, Holms, Sly, Moore and Stackebrandt 1993, $132^{\mathrm{VP}}$. In Bergey's Manual of Systematic Bacteriology, 2nd edn, vol. 2C, pp. 275279. Edited by D. J. Brenner, N. R. Krieg, J. T. Staley \& G. M. Garrity. New York: Springer.

lizuka, H. \& Nishimura, Y. (1969). Microbiological studies on petroleum and natural gas. X. Carotenoid pigments of hydrocarbon-utilizing bacteria. J Gen Appl Microbiol 15, 127-134.

Katayama-Fujimura, Y., Komatsu, Y., Kuraishi, H. \& Kaneko, T. (1984). Estimation of DNA base composition by high performance liquid chromatography of its nuclease P1 hydrolysate. Agric Biol Chem 48, 3169-3172.

Kawahara, K., Seydel, U., Matsuura, M., Danbara, H., Rietschel, E. T. \& Zähringer, U. (1991). Chemical structure of glycosphingolipids isolated from Sphingomonas paucimobilis. FEBS Lett 292, 107-110.

Kumar, S., Tamura, K. \& Nei, M. (2004). MEGA3: integrated software for Molecular Evolutionary Genetics Analysis and sequence alignment. Brief Bioinform 5, 150-163.

Kumar, N. R., Nair, S., Langer, S., Busse, H.-J. \& Kämpfer, P. (2008). Altererythrobacter indicus sp. nov., isolated from wild rice (Porteresia coarctata Tateoka). Int J Syst Evol Microbiol 58, 839-844.

Kwon, K. K., Woo, J.-H., Yang, S.-H., Kang, J.-H., Kang, S. G., Kim, S.-J., Sato, T. \& Kato, C. (2007). Altererythrobacter epoxidivorans gen. 
nov., sp. nov., an epoxide hydrolase-active, mesophilic marine bacterium isolated from cold-seep sediment, and reclassification of Erythrobacter luteolus Yoon et al. 2005 as Altererythrobacter luteolus comb. nov. Int J Syst Evol Microbiol 57, 2207-2211.

Lai, Q., Yuan, J. \& Shao, Z. (2009). Altererythrobacter marinus sp. nov., isolated from deep seawater. Int J Syst Evol Microbiol 59, 2973-2976.

Lorenz, R. T. \& Cysewski, G. R. (2000). Commercial potential for Haematococcus microalgae as a natural source of astaxanthin. Trends Biotechnol 18, 160-167.

Nishijima, M., Araki-Sakai, M. \& Sano, H. (1997). Identification of isoprenoid quinones by frit-FAB liquid chromatography-mass spectrometry for the chemotaxonomy of microorganisms. J Microbiol Methods 28, 113-122.

Pane, L., Radin, L., Franconi, G. \& Carli, A. (1996). The carotenoid pigments of a marine Bacillus firmus strain. Boll Soc Ital Biol Sper 72, 303-308.

Park, S. C., Baik, K. S., Choe, H. N., Lim, C. H., Kim, H. J., Ka, J.-O. \& Seong, C. N. (2011). Altererythrobacter namhicola sp. nov. and Altererythrobacter aestuarii sp. nov., isolated from seawater. Int J Syst Evol Microbiol 61, 709-715.

Renstrom, B., Borch, G., Skulberg, O. M. \& Liaaenjensen, S. (1981). Natural occurrence of enantiomeric and meso-astaxanthin. 3. Optical purity of (3S,3'S)-astaxanthin from Haematococcus pluvialis. Phytochemistry 20, 2561-2564.

Saitou, N. \& Nei, M. (1987). The neighbor-joining method: a new method for reconstructing phylogenetic trees. Mol Biol Evol 4, 406425.

Sambrook, J., Fritsch, E. F. \& Maniatis, T. (1989). Molecular Cloning: a Laboratory Manual, 2nd edn. Cold Spring Harbor, NY: Cold Spring Harbor Laboratory.

Seo, S. H. \& Lee, S. D. (2010). Altererythrobacter marensis sp. nov., isolated from seawater. Int J Syst Evol Microbiol 60, 307-311.

Shiba, T. \& Simidu, U. (1982). Erythrobacter longus gen. nov., sp. nov., an aerobic bacterium which contains bacteriochlorophyll $\alpha$. Int J Syst Bacteriol 32, 211-217.
Thompson, J. D., Higgins, D. G. \& Gibson, T. J. (1994). Clustal w: improving the sensitivity of progressive multiple sequence alignment through sequence weighting, position-specific gap penalties and weight matrix choice. Nucleic Acids Res 22, 4673-4680.

Tsubokura, A., Yoneda, H. \& Mizuta, H. (1999). Paracoccus carotinifaciens sp. nov., a new aerobic Gram-negative astaxanthinproducing bacterium. Int J Syst Bacteriol 49, 277-282.

Xu, X.-W., Wu, Y.-H., Wang, C.-S., Wang, X.-G., Oren, A. \& Wu, M. (2009). Croceicoccus marinus gen. nov., sp. nov., a yellow-pigmented bacterium from deep-sea sediment, and emended description of the family Erythrobacteraceae. Int J Syst Evol Microbiol 59, 2247-2253.

Yabuuchi, E., Yano, I., Oyaizu, H., Hashimoto, Y., Ezaki, T. \& Yamamoto, H. (1990). Proposals of Sphingomonas paucimobilis gen. nov. and comb. nov., Sphingomonas parapaucimobilis sp. nov., Sphingomonas yanoikuyae sp. nov., Sphingomonas adhaesiva sp. nov., Sphingomonas capsulata comb. nov., and two genospecies of the genus Sphingomonas. Microbiol Immunol 34, 99-119.

Yabuuchi, E., Kosako, Y., Naka, T., Suzuki, S. \& Yano, I. (1999). Proposal of Sphingomonas suberifaciens (van Bruggen, Jochimsen and Brown 1990) comb. nov., sphingomonas natatoria (Sly 1985) comb. nov., Sphingomonas ursincola (Yurkov et al. 1997) comb. nov., and emendation of the genus Sphingomonas. Microbiol Immunol 43, 339349.

Yokota, A., Akagawa-Matsushita, M., Hiraishi, A., Katayama, Y., Urakami, T. \& Yamasato, K. (1992). Distributions of quinone systems in microorganisms: Gram-negative eubacteria. Bull Jpn Fed Cult Coll 8, 136-171.

Yoon, J.-H., Kang, K. H., Yeo, S.-H. \& Oh, T.-K. (2005). Erythrobacter luteolus sp. nov., isolated from a tidal flat of the Yellow Sea in Korea. Int J Syst Evol Microbiol 55, 1167-1170.

Yurkov, V., Stackebrandt, E., Holmes, A., Fuerst, J. A., Hugenholtz, P., Golecki, J., Gad'on, N., Gorlenko, V. M., Kompantseva, E. I. \& Drews, G. (1994). Phylogenetic positions of novel aerobic, bacteriochlorophyll a-containing bacteria and description of Roseococcus thiosulfatophilus gen. nov., sp. nov., Erythromicrobium ramosum gen. nov., sp. nov., and Erythrobacter litoralis sp. nov. Int J Syst Bacteriol 44, 427-434. 